\title{
Radial Segmentation of Blood Lymphocytes Nuclei in Pheasants Vaccinated against Newcastle Disease and Haemorrhagic Enteritis
}

\author{
S. GRACZYK, A. WIELICZKOํㅗㄱ, A. PLISZCZAK-KRÓL, B. JANACZYK \\ Division of Pathophysiology, Department of Pathological Anatomy, Pathophysiology, \\ Microbiology and Forensic Veterinary Medicine, \\ ${ }^{3.1}$ Department of Epizootiology and Administration with Clinic, Faculty of Veterinary Medicine, Wroclaw \\ University of Environmental and Life Sciences, \\ Wroclaw, Poland \\ Received February 1, 2007 \\ Accepted October 1, 2008
}

\begin{abstract}
Graczyk S., A. Wieliczko, A. Pliszczak-Król, B. Janaczyk: Radial Segmentation of Blood Lymphocytes Nuclei in Pheasants Vaccinated against Newcastle Disease and Haemorrhagic Enteritis. Acta Vet. Brno 2008, 77: 625-630.

The purpose of the experiment was to investigate the influence of the pheasant vaccination with a vaccine containing live attenuated virus of haemorrhagic enteritis, (HE) on the ability of peripheral blood lymphocytes to form a nuclei deformation described as the radial segmentation (RS). This feature is identified with cytoskeletal rearrangement of the cells. The pheasants were vaccinated against Newcastle disease (ND) on the $1^{\text {st }}, 28^{\text {th }}$ and $56^{\text {th }}$ day of life. Moreover, on the $49^{\text {th }}$ day of life, a part of the birds was given the vaccine containing HEV (Haemorrhagic enteritis virus) in drinking water.

Fourteen days after the HEV vaccination, the birds were administered intravenously $0.5 \mathrm{ml}$ of the $10 \%$ SRBC (Sheep red blood cells) suspension. Blood samples were collected on the $21^{\text {st }}$ day after $\mathrm{HEV}$ vaccination, on the $7^{\text {th }}$ day after SRBC injection.

It was shown that in pheasants the percentage of cells undergoing RS induced by oxalates was low, approximately $3.75 \%$, whereas in HEV vaccinated birds this percentage increased twice $(p<0.05)$. Pheasant immunization with SRBC led to significant reduction of the ability to form RS, whereas in HEV vaccinated birds after SRBC administration the percentage of cells with RS remained on the level of the control group.

Based on these results, the authors suggest that immunosuppressive effects of some viruses may be a result of both sensitivity and rearrangement ability changes in cytoskeletal proteins of the cells involved in immunological response.
\end{abstract}

Phasianus colchicus, leukocytes, radial segmentation of the nuclei (RS), NDV, HEV, SRBC

The main task of the immune system of an organism is to distinguish between what is its own and what is foreign and to eliminate any threat that may impair homeostasis. The threat is recognized much faster, when the factor causing it is known. This knowledge is the basis of prophylactic vaccinations with attenuated pathogenic antigens given. Final effects of vaccination depend not only on pathogen virulence, but also on interaction with other factors, often leading to immunosuppression (Słowik et al. 1990; Dohms and Metz 1991; Boa-Amponsem et al. 1999; Rautenschlein and Sharma 1999; Kulikova et al. 2004; Ganapathy 2005).

Viruses deteriorating the reactivity of the immune system in birds include adenoviruses, such as the very important one in pheasants MSDV - Marble spleen disease virus. This virus is very closely related to the HEV - Haemorrhagic enteritis virus in turkeys and AAS - Avian adenovirus splenomegaly (Pierson and Fitzgerald 2003).

Infections caused by these viruses are very common. In Poland, the presence of specific anti-HEV antibodies in ring-necked pheasants (Phasianus colchicus L.) was found in $66.7 \%$ of flocks under investigation (Wieliczko et al. 2003). These infections usually show no

Address for correspondence:

Prof. Dr. Hab. Stanislaw Graczyk

Division of Pathophysiology,

Faculty of Veterinary Medicine

Wroclaw University of Environmental and Life Sciences

Norwida 31, 50-375 Wrocław, Poland 
symptoms, but consequently lead to immunosuppression. Immunosuppression induced by HEV facilitates secondary infections, especially with E. coli or coccidia (Sponenberg et al. 1985; Ahmad and Sharma 1993; Pierson et. al. 1996). The mechanisms of immunosuppression are still not well known. A direct influence of viruses on the function of lymphocytes has been suggested. It was shown that a decreased level of B lymphocytes after chemical bursectomy gave protective effects against MSD after experimental infection of pheasants (Fitzgerald and Reed 1991).

Experiments on birds treated with cyclosporine also suggest that $\mathrm{T}$ lymphocytes and thus cell-mediated immunity are of great importance in response to MSDV infection and MSD pathogenesis (Fitzgerald et al. 1995).

In the course of lymphocyte activation, many functional and morphological changes are observed, in which a major role is ascribed to cytoskeletal microtubules. These changes are the manifestation of numerous processes taking place in cells. They are connected with cytoplasm reorganization and intracellular transport occurring in both maturing and mature leukocytes, as well as in lymphocytes activated by mitogens or in neoplastic ones (Ding et al. 1995; Serrador et al. 1999; Small et al. 1999; Sumoza-Toledo and SantosArgumendo 2004; Eash and Atwood 2005).

In the 1970s, Norberg and Söderström indicated in numerous studies a relation between the reorganization of cytoskeletal proteins, including tubulin, and the ability of lymphocyte nuclei to deform. They named the observed process "radial segmentation" (RS) (Norberg and Söderström 1967; Söderström et al. 1976).

In our own previous investigations, changes were shown of the percentage of the lymphocytes with nuclei undergone the RS in birds after bursectomy, or in animals stimulated with antigen. We have suggested a relation of the observed changes with the immunosuppression appearing after bursectomy (Graczyk and Pliszczak-Król 1996; Pliszczak-Król 2002). Modification of the RS percentage was also observed in chickens treated with ACTH (Pliszczak-Król 2001).

Considering the above facts, in the present study an evaluation was made of the ability of blood lymphocytes to form RS nuclei in pheasants vaccinated against ND, and additionally immunized with a vaccine containing an attenuated strain of HEV. The procedure allows investigating whether and how the cytoskeletal structures of the cells involved in immunogenesis take part in the course of immunological stress, induced by simultaneous bird immunization with vaccine viruses.

\section{Materials and Methods}

The material consisted of 40 pheasants, male and female, purchased from a pheasantry at the age of $1 \mathrm{~d}$. After several days of acclimatisation, the birds were divided into four groups (each $n=10)$ and put in cages placed in separate boxes. All birds were fed a complete mixture for pheasants ad libitum and had free access to water. During the entire experimental period, the birds were fed the same diet and were provided with identical zoohygienic conditions. All the pheasants were prophylactically vaccinated at one day of age against ND using spray with the Pestos vaccine (Merial), and next, on days 28 and 56 of age, they were given Sotasec vaccine (Merial) in drinking water, according to manufacturers' recommendations. Moreover, 49-day-old birds from two groups (group 3 and 4) were given drinking water containing Dindoral SPF (Merial), a commercial vaccine with the Domermuth HEV strain. It is generally recommended for active immunization of turkey broilers against HEV and of pheasants against MSDV.

On day 63 of the experiment, i.e. 14 days after HEV vaccination, the birds in groups 2 and 4 were intravenously

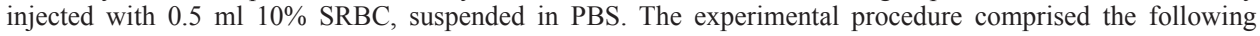
groups:

Group 1 - NDV vaccinated pheasants

Group 2 - NDV + SRBC vaccinated pheasants

Group 3 - NDV + HEV vaccinated pheasants

Group 4 - NDV + HEV + SRBC vaccinated pheasants

The control of presence of anti-NDV antibodies was performed by the haemagglutination inhibition test (HI 
test) using an antigen produced by the State Veterinary Institute in Puławy (Instruction No. GIWZ VII-420/ lab-2/2003 on diagnostic tests for Newcastle disease). Specific anti-ND antibodies were found in all examined birds.

The presence of anti-HEV antibodies was determined using precipitation reaction in the agar gel (AGP), with the use of pheasant serum and HE antigen (Spafas, USA). The AGP test was performed using Noble Difco Agar, in parallel to the investigated sera and with positive HE reagent serum (Spafas, USA). The result was read 24 and $48 \mathrm{~h}$ after incubation in a humid chamber at $25^{\circ} \mathrm{C}$.

Birds non-vaccinated with HEV showed a lack of anti-HEV antibodies.

Blood samples were collected on the $21^{\text {st }}$ day after HEV vaccination, i.e. 7 days after SRBC administration. Smears were made from collected blood. The percentage of leukocytes was determined by counting up to 200 cells, and the leukogram was counted.

Heparinized blood was used to perform a test, in which blood samples were incubated with oxalate mixture to determine the ability of mononuclear cells to form RS (test RS). The test of spontaneous and induced radial segmentation (RS) was performed after the method of Söderström et al. (1976) with own modifications (Graczyk and Pliszczak-Król 1996; Pliszczak-Król 2002). Blood samples were divided in two equal units, $0.8 \mathrm{ml}$ each. The first one represented control (spontaneous RS). The $0.2 \mathrm{ml}$ mixture of potassium and ammonium oxalate at a $1: 1$ ratio was added to the second blood unit (induced RS). Both specimens were incubated for $3 \mathrm{~h}$ at room temperature of 21-23 ${ }^{\circ} \mathrm{C}$ (about 294-296 K). After the incubation, 2 smears from each bird were prepared from the upper part of centrifuged blood and stained according to May-Grünwald-Giemsa method. In each of the smears, the encountered mononuclear cells were counted to 200 and differentiated as RS-positive (RS+) and RS-negative (RS-). The cell nuclei with fissures of at least $1 / 3$ of the nucleus diameter were admitted as a RS+ (Plate II, Fig. 1). The results of RS test were shown as a medium range obtained in each group. The results obtained in the study were analyzed statistically, using Student's $t$-test. The differences were considered significant at $p<0.05$.

\section{Results}

Table 1 shows the percentage of particular leukocytes in the investigated birds. In the control group lymphocytes predominated (about 70\%). The percentage of heterophils, analogues to mammalian neutrophils, was 20\%. The basophils and eosinophils formed $4 \%$ and $2 \%$, respectively. Similar relations were observed in the rest of investigated groups of birds. However, in group of pheasants immunized with SRBC (group 2), the heterophil and lymphocyte percentage changed significantly. The lymphocyte percentage decreased by $17 \%$, simultaneously with almost $50 \%$ increase of heterophils percentage (Table 1).

Table 1. Percentage of leukocytes in pheasants' blood

\begin{tabular}{|c|c|c|c|c|c|}
\hline Group & Lymphocytes \% & Heterophils \% & Eosinocytes \% & Basophils \% & Monocytes \% \\
\hline $\begin{array}{c}1 \\
\text { (NDV) }\end{array}$ & $70.66 \pm 11.09$ & $22.66 \pm 11.02$ & $2 \pm 1.67$ & $4.16 \pm 3.71$ & $0.5 \pm 0.54$ \\
\hline $\begin{array}{c}2 \\
(\mathrm{NDV}+\mathrm{SRBC})\end{array}$ & $59 \pm 14.96$ & $33.66 \pm 16.05$ & $1 \pm 1.55$ & $6 \pm 2.96$ & $0.33 \pm 0.81$ \\
\hline $\begin{array}{c}3 \\
(\mathrm{NDV}+\mathrm{HEV})\end{array}$ & $65.5 \pm 6.02$ & $22.5 \pm 5.82$ & $5.33 \pm 3.98$ & $5.33 \pm 5.12$ & $1.33 \pm 1.96$ \\
\hline $\begin{array}{c}4 \\
(\mathrm{NDV}+\mathrm{HEV}+ \\
\text { SRBC }\end{array}$ & $65.16 \pm 5.15$ & $24.33 \pm 6.25$ & $2.66 \pm 3.07$ & $7.66 \pm 3.14$ & $0.16 \pm 0.41$ \\
\hline
\end{tabular}

After $3 \mathrm{~h}$ of incubation with the oxalate mixture, about $3.75 \%$ of mononuclear cells in the control group formed RS. In the group of SRBC-immunised pheasants (group 2), the percentage of RS + cells decreased significantly $(p<0.05)$. However, birds vaccinated against HE (group 3) showed twice as high percentage of RS+ cells than birds from the control group. The percentage of RS cells changed non-significantly in the pheasants immunised with SRBC and previously vaccinated against HE (Table 2).

\section{Discussion}

The aim of the experiment was to evaluate the ability of peripheral blood lymphocytes to form radial segmentation of their nuclei. The ability to form RS was estimated in parallel to 
Table 2. The percentage of lymphocyte nuclei undergoing RS in experimental pheasants

\begin{tabular}{|c|c|c|}
\hline Group & $\begin{array}{c}\text { Lymphocytes with RS } \\
\text { induced with oxalates \% }\end{array}$ & $\begin{array}{c}\text { Lymphocytes } \\
\text { with spontaneous RS \% }\end{array}$ \\
\hline $\begin{array}{c}1 \\
(\mathrm{NDV})\end{array}$ & $3.75 \pm 3.27$ & $0.1 \pm 0.29$ \\
\hline $\begin{array}{c}\text { (NDV + SRBC) } \\
3\end{array}$ & $1.42 * \pm 1.73$ & $0.1 \pm 0.29$ \\
\hline $\begin{array}{c}\text { NDV+ HEV) } \\
4\end{array}$ & $7.58^{*} \pm 5.36$ & $0.1 \pm 0.29$ \\
\hline$(\mathrm{NDV}+\mathrm{HEV}+\mathrm{SRBC})$ & $4.42 \pm 3.60$ & $0.42 \pm 0.79$ \\
\hline
\end{tabular}

* Difference significant at $p<0.05$ the leukogram analysis. The results of the latter are very similar to data presented by Hauptmanova et al. (2006).

In the available literature no data were found, relevant to the blood picture of pheasants exposed to stressors. Stress is one of the most important processes modulating reactivity of the bird's immune system (Dohms and Metz 1991). The effects of different environmental stressors, such as manipulation and vaccination, activate the adaptive process, appearing as stress. Numerous stress symptoms include a very sensitive one, the ratio change of heterophils and lymphocytes (Dohms and Metz 1991; Graczyk et al. 2003). In this context, no significant change of the described relation observed in the investigated birds indicates that complete adaptation to surrounding conditions took place. Moreover, the immune stress caused by vaccination may have attenuated with time.

The evidence is an increase of the percentage of heterophils and a simultaneous decrease of lymphocytes on day 7 after SRBC administration. Interestingly, we noticed a lack of the same changes in pheasants immunized with SRBC, which were previously vaccinated against HE. It may be a result of adaptation, or a manifestation of reactivity of white blood cell system in pheasants, different than in other species. To confirm the above observation, further experiments, on a larger group of birds, are required.

The dominant leukocyte populations in pheasants are mononuclear cells with lymphocytes among them. According to the initial assumption, an attempt was made to evaluate the ability of peripheral blood lymphocytes to form radial segmentation (RS). We relayed on the observations that function and morphology of the cells change upon different agents (Pliszczak-Król 2001; Pliszczak-Król 2002). Based on our previous observations and other authors' reports, the RS of lymphocyte nuclei was assumed as an expression of the cytoskeletal condition of these cells (Söderström et al. 1976; Ding et al. 1995; Pliszczak-Król 2001). As opposed to chickens (Graczyk and PliszczakKról 1996; Pliszczak-Król 2001; Pliszczak-Król 2002), in pheasants only about $3.75 \%$ of peripheral blood lymphocytes undergo RS. After SRBC administration, similarly to chickens (Pliszczak-Król 2002), the percentage of RS+ cells significantly decreased $(p<0.05)$; whereas in birds vaccinated against HEV the percentage of lymphocytes with $\mathrm{RS}$ increased twice. Because the process of RS formation is still not fully understood, the mechanism of presented changes is difficult to explain. Comparing presented data and results of previous experiments (on chicken material) we can state that, independently of the bird species, SRBC administration reduces the ability of lymphocytes to form radial segmentation of their nuclei. The increase of RS+ lymphocytes in birds vaccinated with HEV suggests complex immunosuppressive mechanism of a vaccine virus. The vaccine possesses an immunosuppressive function on specific agglutinin production in pheasants, which was described in a previous study (Graczyk et al. 2006). Because the ability to form RS was examined on the $21^{\text {st }}$ day after HEV vaccination and on the $7^{\text {th }}$ day after SRBC administration, one may suspect that changes in the percentage of RS+ cells, together with a decreased level of antibodies, were the result of reactivity changes of the cells, taking place in the course of the antigenic response. This interpretation is based on the comparison 
of the percentage of RS+ cells in birds stimulated with SRBC, and the percentage of RS+ lymphocytes found in pheasants vaccinated against $\mathrm{HEV}$, which were also given SRBC. In the last group of birds, the RS+ lymphocyte percentage $(4.42 \%)$ seems to be a resul of the $\mathrm{SRBC}$ action and stimulating influence of $\mathrm{HE}$ virus.

It is possible that the observed changes are the result of alteration in the intracellular calcium content provoked by a vaccine virus. Such alteration was found in chicken phagocytic cells, activated with LPS (Yong et al. 2005). On the other hand, experiments based on calcium ion chelation and subsequent re-calcification, proved that the intracellular changes in the $\mathrm{Ca}^{2+}$ content take part in nuclei deformation that is radial segmentation (Norberg and Söderström 1967). Changes in the calcium ion content were not examined in this study; however, we assume that the observed changes of pheasants' blood lymphocyte ability to form RS nuclei are due to the altered calcium balance caused by the presence of the virus. The changes in cytoskeleton were found in the experiment with apoptosis of spleen cells, induced by adenoviruses, which may be an indirect verification of the above hypothesis (Lewis et al. 1998; Rautenschlein et al. 2000; Eash and Atwood 2005). However, further investigations are required.

In conclusion, the evaluation of peripheral blood lymphocyte ability to form radial segmentation of their nuclei sheds new light on the immunosuppression mechanisms observed in practice. The experiment indicates that the main reason may be the changes in cytoskeleton of the cells taking part in immunogenesis.

\section{Výskyt radiální segmentace lymfocytárních jader v periferní krvi bažantů vakcinovaných proti Newcastleské chorobě a hemoragické enteritidě}

Cílem této studie bylo posouzení vlivu aktivní imunizace bažantů živou atenuovanou vakcínou proti hemoragické enteritidě (HE) na tvorbu aberantní formy lymfocytů s radiálně segmentovanými jádry (RS). Podstatou této změny je transformace cytoskeletárního aparátu lymfocytů. Profylaktická vakcinace bažantů proti Newcastleské chorobě (ND) byla prováděna ve věku 1, 28 a 56 dní. Vakcinace proti hemoragické enteritidě byla provedena u části pokusných zvírat 49. den života aplikací v pitné vodě. Za 14 dní po imunizaci virem hemoragické enteritidy (HEV) byla intravenózně aplikována 10\% suspenze ovčích erytrocytů (SRBC) v dávce $0.5 \mathrm{ml}$. Vzorky krve byl odebrány 21 dní po HEV vakcinaci resp. 7 dní po aplikaci SRBC.

Bylo zjištěno, že radiální segmentace jader lymfocytů v krvi bažantů vyvolaná účinkem št'avelanů se objevuje pouze u malého množství buněk, přibližně u $3.75 \%$ lymfocytů, zatímco aktivní imunizace virem hemoragické enteritidy způsobí RS u dvojnásobného množství lymfocytů $(p<0.05)$. Vakcinace bažantů s následnou aplikací SRBC vedla k signifikantnímu poklesu tvorby RS, na druhou stranu procentuální zastoupení lymfocytů s RS indukované HEV vakcinací následující po podání SRBC bylo shodné s výskytem RS v kontrolní skupině. Z těchto výsledkủ vyplývá, že imunologická odpověd' po použití živých atenuovaných vakcín může být doprovázena imunosupresivními účinky některých virů, které se projevují zvýšením senzitivity a schopnosti transformačních změn proteinů tvořících cytoskeletární aparát buňky.

\section{References}

AHMAD J, SHARMA JM 1993: Protection against haemorrhagic enteritis and Newcastle disease in turkeys by embryo vaccination with monovalent and bivalent vaccines. Avian Dis 37: 485-491

BOA-AMPONSEM K, LARSEN CT, DUNNINGTON EA, SIEGEL PB 1999: Immunocompetence and resistance to marble spleen disease of broiler- and layer-type pure lines of chickens. Avian Pathol 28: 397-384

DING M, ROBINSON JM, BEHRENS BC, VANDRE DD 1995; The microtubule cytoskeleton in human phagocytic leukocytes is a highly dynamic structure. Eur J Cell Biol 66: 234-245

DOHMS JE, METZ A 1991: Stress mechanisms of immunosuppression. Vet Immunol Immunopathol 30: 89-109 
EASH S, ATWOOD WJ 2005: Involvement of cytoskeletal components in BK virus infectious entry. J Virol 79: 11734-11741

FITZGERALD SD, REED WM, FURUKAWAAM, ZIMELS E, FUNG L 1995: Effect of T-lymphocyte depletion on the pathogenesis of marble spleen disease virus infection in ring-necked pheasants. Avian Dis 39: 68-73

FITZGERALD SD, REED WM 1991: Pathogenesis of marble spleen disease in bursectomized and nonbursectomized ring-necked pheasants following oral inoculation with cell-culture-propagated virus. Avian Dis 35: $579-584$

GANAPATHY K, CARGILL P, MONTIEL E, JONES RC 2005: Interaction between live avian pneumovirus and Newcastle disease virus vaccines in specific pathogen free chickens. Avian Pathol 34: 297-302

GRACZYK S, PLISZCZAK-KRÓL A 1996: Preliminary studies on radial segmentation (RS) of nuclei in hens' blood lymphocytes. Sci Lett (Wroclaw Agric University) 55: 15-24 (in Polish)

GRACZYK S, PLISZCZAK-KRÓL A, KOTOŃSKI B, WILCZEK J, CHMIELAK Z 2003: Examinations of haematological and metabolic changes mechanisms of acute stress in turkeys. EJPAU, Vet Med 6: \#05 (Available online: http://www.ejpau.media.pl/volume6/issue1/veterinary/art-05.html )

GRACZYK S, WIELICZKO A, PLISZCZAK-KRÓL A, JANACZYK B 2006: Humoral and cellular response of pheasants vaccinated against Newcastle disease and haemorrhagic enteritis. Acta Vet Brno 75: 379-386

HAUPTMANOVA K, MALY M, LITERAK I 2006: Changes of haematological parameters in common pheasant throughout the year. Vet Med-Czech 51: 29-34

KULIKOVA L, JURAJDA V, JURANOVA R 2004: Effects of infectious bursal disease vaccination strains on the immune system of leghorn chickens. Acta Vet Brno 73: 205-209

LEWIS M L, REYNOLDS JL, CUBANO LA, HATTON JP, LAWLESS BD, PIEPMEIER EH 1998: Spaceflight alters microtubules and increases apoptosis in human lymphocytes (Jurkat). Faseb J 12: 1007-1018

NORBERG B, SÖDERSTRÖM N 1967: "Radial segmentation" of the nuclei in lymphocytes and other blood cells induced by some anticoagulants. Scand J Haemat 4: 68-76

PIERSON FW, FITZGERALD SD 2003: Haemorrhagic enteritis and related infections. In: SAIF YM: Diseases of poultry, $11^{\text {th }}$ ed. Iowa Press, pp. 237-247

PIERSON FW, LARSEN CT, DOMERMUTH CH 1996: The production of colibacillosis in turkeys following sequential exposure to Newcastle disease virus or Bordetella avium, avirulent haemorrhagic enteritis virus, and Escherichia coli. Avian Dis 40: 837-840

PLISZCZAK-KRÓL A 2001: The influence of ACTH on the RS of nuclei and acid phosphatase activity in blood lymphocytes of immunized chickens. Med Weter 57: 676-679 (in Polish)

PLISZCZAK-KRÓL A 2002: The role of central and peripheral lymphatic organs in radial segmentation of nuclei (RS) and acid phosphatase activity of blood lymphocytes in immunized chickens. Med Weter 1: 81-101 (in Polish)

RAUTENSCHLEIN S, SHARMA JM 1999: Response of turkeys to simultaneous vaccination with haemorrhagic enteritis and Newcastle disease viruses. Avian Dis 43: 286-292

RAUTENSCHLEIN S, SURESH M, SHARMA JM 2000: Pathogenic avian adenovirus type II induces apoptosis in turkey spleen cells. Arch Virol 145: 1671-1683

SERRADOR JM, NIETO M, SANCHEZ-MADRID F 1999: Cytoskeletal rearrangement during migration and activation of T lymphocytes. Trends Cell Biol 9: 228-232

SŁOWIK J, GRACZYK S, GOLNIK W, PAWESKA J 1990: Immunological response of bursectomized and non-bursectomized chickens inoculated with Newcastle disease virus (NDV), after administration of sheep red blood cells (SRBC) or bovine serum albumin (BSA). Pol Arch Weter 30: 101-112 (in Polish)

SMALL JV, KAVERINA I, KRYLYSHKINA O, ROTTNER K 1999: Cytoskeleton cross-talk during cell motility. FEBS Lett 452: 96-99

SÖDERSTRÖM UB, NORBERG B, BRANDT L 1976: The oxalate-induced radial segmentation of the nuclei in peripheral blood lymphocytes of different size. Scand J Haematol 17: 57-61

SPONENBERG DP, DOMERMUTH CH, LARSEN CT 1985: Field outbreaks of colibacillosis of turkeys associated with haemorrhagic enteritis virus. Avian Dis 29: 838-842

SUMOZA-TOLEDO A, SANTOS-ARGUMENDO L 2004: The spreading of B lymphocytes induced by CD44 cross-linking requires actin, tubulin, and vimentin rearrangements. J Leukoc Biol 75: 233-239

SURESH M, SHARMA JM 1995: Haemorrhagic enteritis virus induced changes in the lymphocyte subpopulations in turkeys and the effect of experimental immunodeficiency on viral pathogenesis. Vet Immunol Immunopathol 45: $139-150$

WIELICZKO A, TOMANEK B, KUCZKOWSKI M 2003: Prevalence of infectious diseases in ring-necked pheasant flocks in Poland. Pol J Vet Sci 6: 177-182

YONG S, ABE A, HAN S, KONDO Y 2005; Intracellular calcium ion elevation in chicken phagocytes treated with activating agents. J Poult Sci 42: 14-23 
Plate II

Graczyk S. et al.: Radial Segmentation ... pp. 625-630

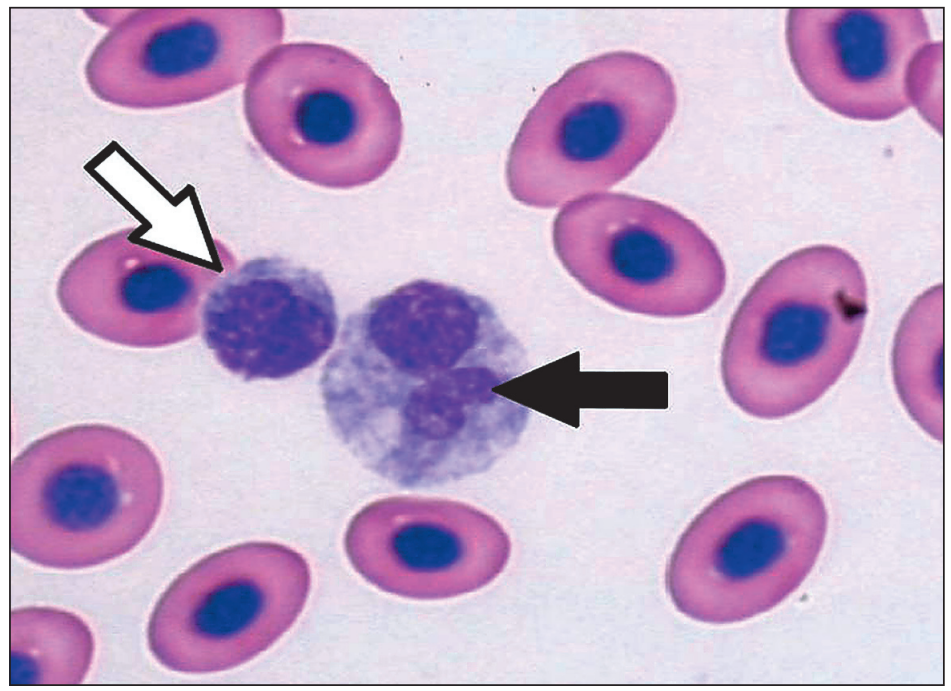

Fig. 1. Radial segmentation (RS) of the lymphocyte nuclei in pheasants.

$\Rightarrow$ - normal lymphocyte

$\vec{\longrightarrow}$ - lymphocyte with RS 
